\title{
TMC (Thrissur Medical College) modified Robson criteria for caesarean sections
}

\author{
K. J. Jacob, Megha Jayaprakash*, Hibina K. P.
}

Department of Obstetrics and Gynecology, Government Medical College, Thrissur, Kerala, India

Received: 29 August 2017

Accepted: 25 September 2017

\section{*Correspondence:}

Dr. Megha Jayaprakash,

E-mail: meghajayaprakash@yahoo.co.in

Copyright: ( $)$ the author(s), publisher and licensee Medip Academy. This is an open-access article distributed under the terms of the Creative Commons Attribution Non-Commercial License, which permits unrestricted non-commercial use, distribution, and reproduction in any medium, provided the original work is properly cited.

\begin{abstract}
Background: The Robson system is the most widely accepted classification system available for analysing characteristics of delivering women worldwide. Several authors have tried modifications in the existing system. The objective of this study was to modify the existing system with relevance to caesarean section rates in various obstetric population and to identify major factors contributing to it.

Methods: This study was performed in Government Medical College, Thrissur from January 2017 to June 2017. All women delivered during this period were classified according to the modified system consisting of 8 groups using their maternal characteristics and obstetric history. Each major group were sub classified into 3: women who went into spontaneous labour/ induced labour/ CS done before labour. For each group, we calculated the contribution to overall CS and Primary CS separately. Women with Previous CS were analyzed as a separate group. This classification was intended to directly estimate primary as well as repeat CS rates and indirectly the VBAC rates. Results: Out of total 1337 women delivered, 413 underwent CS (30.8\%). The contribution made by previous CS group to overall CS was $61.5 \%$, and the repeat section rate was $91.3 \%$. The primary CS rate was $15 \%$ and the maximum contribution was made by term induced primigravida followed by Primigravida with Breech presentation. VBAC rate was $8.6 \%$.

Conclusions: Our modified Robson system can be effectively utilized in analysing delivering women and provide valuable information regarding the delivery characteristics with particular relevance to Caesarean sections.
\end{abstract}

Keywords: Caesarean section, Robson classification system

\section{INTRODUCTION}

In 1985, WHO has proposed the ideal rate for caesarean sections to be between $10-15 \%$.

Since then, CS has become increasingly common in both developing and developed countries. When medically justified, a CS can effectively prevent maternal and perinatal mortality and morbidity.

However, there is no evidence showing the benefits of caesarean delivery for women or infants who do not require the procedure. There is a need for an internationally accepted classification system for caesarean sections that would allow meaningful and relevant comparison of CS rates. Among the classification systems available, the 'Robson' system has been widely used in various countries.

This system was proposed by Dr. Michael Robson in 2001. WHO also recommends this system as a global standard for assessing, monitoring and comparing CS rates within healthcare facilities over time (WHO systematic review 2011). It consists of 10 patient population categories that are mutually exclusive. The categories are based on 5 basic obstetric characteristics. 
- Parity

- Onset of labor

- Gestational age

- Fetal presentation

- No. of fetuses.

\section{Robson classification system}

- Class 1: Nullipara, equal to or $>37$ weeks, single, cephalic, spontaneous labor

- Class 2: Nullipara, equal to or $>37$ weeks, single, cephalic, induced labor or CS before labor
i. $\quad 2 \mathrm{a}$ : induced labor
ii. $2 \mathrm{~b}$ : CS before labor

- Class 3: Multipara, equal to or >37 weeks, single, cephalic, spontaneous labor (excludes previous CS)
- Class 4: Multipara, equal to or >37 weeks, single, cephalic, induced or CS before labor (excludes previous CS)
i. $\quad 4 a$ : induced labor
ii. $4 \mathrm{~b}$ : $\mathrm{CS}$ before labor

- Class 5: Multipara, previous CS, equal to or $>37$ weeks, single, cephalic

- Class 6: Nullipara, single, breech

- Class 7: Multipara, single, breech (including previous CS)

- Class 8: Multiple pregnancy (with or without previous CS)

- Class 9: Singleton pregnancy, oblique/transverse lie (with or without previous CS)

- Class 10: Single, cephalic <37 weeks (including previous CS).

Table 1: TMC modified Robson's classification.

\begin{tabular}{|c|c|c|c|c|c|c|c|}
\hline Major group & Subgroup & $\begin{array}{l}\text { No. of } \\
\text { women } \\
\text { in the } \\
\text { group } \\
\text { (a) }\end{array}$ & $\begin{array}{l}\text { Relative } \\
\text { size of } \\
\text { the } \\
\text { group } \\
\text { (b) }\end{array}$ & $\begin{array}{l}\text { No. } \\
\text { of CS } \\
\text { (c) }\end{array}$ & $\begin{array}{l}\text { CS rate in } \\
\text { the } \\
\text { group } \\
\text { (d) }\end{array}$ & $\begin{array}{l}\text { Contribution } \\
\text { made by the } \\
\text { group to } \\
\text { overall CS } \\
\text { rate(e) }\end{array}$ & $\begin{array}{l}\text { Contribution } \\
\text { made by the } \\
\text { group to } \\
\text { primary CS } \\
\text { rate (f) }\end{array}$ \\
\hline \multirow{3}{*}{$\begin{array}{l}\text { Nullipara, single, } \\
\text { cephalic, equal to or } \\
>37 \text { weeks }\end{array}$} & A) Spontaneous & & & & & & \\
\hline & B) Induced & & & & & & \\
\hline & C) CS before labou & & & & & & \\
\hline \multirow{3}{*}{$\begin{array}{l}\text { Multipara, single, } \\
\text { cephalic equal to or }>37 \\
\text { weeks (excluding } \\
\text { previous CS) }\end{array}$} & A) Spontaneous & & & & & & \\
\hline & B) Induced & & & & & & \\
\hline & C) CS before labou & & & & & & \\
\hline \multirow{3}{*}{$\begin{array}{l}\text { All single, cephalic }<37 \\
\text { weeks (excluding } \\
\text { previous CS) }\end{array}$} & A) Spontaneous & & & & & & \\
\hline & B) Induced & & & & & & \\
\hline & C) CS before labou & & & & & & \\
\hline \multirow{3}{*}{ All nulliparous breech } & A) Spontaneous & & & & & & \\
\hline & B) Induced & & & & & & \\
\hline & C) CS before labou & & & & & & \\
\hline \multirow{3}{*}{$\begin{array}{l}\text { All multiparous breech } \\
\text { (excluding previous } \\
\text { CS) }\end{array}$} & A) Spontaneous & & & & & & \\
\hline & B) Induced & & & & & & \\
\hline & C) CS before labou & & & & & & \\
\hline \multirow{3}{*}{$\begin{array}{l}\text { All multiple } \\
\text { pregnancies (excluding } \\
\text { previous CS) }\end{array}$} & A) Spontaneous & & & & & & \\
\hline & B) Induced & & & & & & \\
\hline & C) CS before labou & & & & & & \\
\hline \multirow{3}{*}{$\begin{array}{l}\text { All abnormal lie } \\
\text { (excluding previous } \\
\text { CS) }\end{array}$} & A) Spontaneous & & & & & & \\
\hline & B) Induced & & & & & & \\
\hline & C) CS before labou & & & & & & \\
\hline $\begin{array}{l}\text { Total (last column } \\
\text { shows primary CS rate) }\end{array}$ & & $\mathrm{X}$ & & $\mathrm{Y}$ & & & $\mathrm{Y} / \mathrm{x} * 100$ \\
\hline
\end{tabular}

This classification is simple, systematic, reproducible, and prospective and gives excellent information regarding the delivering population. But, certain limitations can be cited.

This classification does not include any information regarding indications for induction or CS. It also does not account for pre-existing medical, surgical or foetal disease and the degree of prematurity; all of which may influence the rate of CS. No information regarding women who have undergone Trial of labour after CS (TOLAC) is obtained. But it is practically impossible to include such finer details in a comprehensive classification system like this. The growing CS rates and 
thus number of previous CS encouraged us to try certain modifications in the existing system whereby we have tried to simplify the entire classification in such a way as to obtain more detailed information regarding the delivering women, without losing much of its original characteristics.

We felt that the primary and repeat CS rates should be analyzed separately so as to understand factors responsible for growing CS rates which would help us to plan strategies to control it. Studies worldwide have pointed out the increasing labour inductions leading to more number of Caesareans. In this context, we thought of analysing the same in our modified system. The modifications we tried are as follows:

\section{Modification 1}

- Groups are originally sub divided into: no sub group / sub group (a) and (b) / sub group (a), (b) and (c). This non- uniformity can be avoided by uniformly sub dividing each group into 3 , that is (a), (b) and (c) (Table 1)

- This helps for easy understanding and remembrance

- This helps to reduce the number of groups into 8 instead of 10 .

\section{Modification 2}

- The Previous CS originally distributed in variety of groups is made a separate group (Table 1)

- This helps to target our attention to Primary CS rate which is the most important parameter we need to target to reduce the overall CS rate

- This helps to study the VBAC rate also.

\section{Modification 3}

- Additional column for "Contribution made by each group to overall Primary CS rate" (column F) is added on the extreme right (Table 1)

- This helps to calculate primary CS rate for each sub group, thus the major contributors for the CS rate (other than previous CS) is projected out and appropriate interventions can be targeted to these sub groups. A contribution to primary CS rate of equal to or more than $10 \%$ may be taken as significant.

\section{Modification 4}

- An additional row is added as the last but one for calculation of Overall Primary CS rate (Table 1)

- Sum of column C (Total no. of primary CS = Y) divided by sum of column A (total no. of deliveries other than previous. $\mathrm{CS}=\mathrm{X}$ ) multiplied by 100 gives the primary $\mathrm{CS}$ rate $(\mathrm{Y} / \mathrm{X} * 100)$

Accordingly, the modified Robson's system can be tabulated as follows (modifications highlighted in red)

\section{METHODS}

This study was performed in the Department of Obstetrics and Gynecology at Government Medical College, Thrissur from January 2017 to June 2017. All women who delivered during this period were included. Relevant obstetric data were collected and women were classified according to the modified system. For each group, the contribution to overall CS and primary CS rates were calculated and analysed. Women with previous CS were analysed as a separate group. The primary CS rate and repeat $\mathrm{CS}$ rates were calculated for the period of study.

\section{RESULTS}

A total of 1337 women delivered in our institution from January to June 2017.

All women who delivered were classified according to our modified Robson system. Every woman who delivered was classified into one of the 8 groups, which were further sub classified into 3 groups.

All women with a previous CS were classified into separate group (group 8). 924 women delivered vaginally and 413 women underwent CS $(30.8 \%)$. Maximum no. of women was in group 1 (421), followed by group 2 (363). Least number of women was in group 7.

There were 278 women in group 8 (all Previous CS) which is approximately $21 \%$ of all patients delivered, out of which 254 underwent repeat CS (91.3\%), which is $61.5 \%$ of the overall CS. The VBAC rate is only $8.6 \%$ establishing the fact that due to many reasons TOLAC is sparingly practiced.

In the remaining 1059 women, 159 underwent CS. Thus, primary CS rate is $15 \%$. The maximum contribution $(30.8 \%)$ to primary CS rate was by induced term primi with vertex presenting baby -Group 1 (a) followed by Group 1 (c), term primi with vertex presenting baby who had prelabour CS (16.3\%). Primigravida with breech presentation is also a major contributor to primary CS (11.3\%).

\section{DISCUSSION}

WHO has proposed the Robson's ten group classification system as a global standard for assessing, monitoring and comparing CS rates within and between healthcare facilities in 2015 based on two multi country surveys., ${ }^{1,2}$ Several regional and international studies have analysed the utility of this system to identify factors contributing to increasing CS rates which is a growing global concern. Makhanya et al recommends this system for auditing CS rates within healthcare systems. ${ }^{3}$

In the present study, the major contribution to overall CS is by group 8 (women with previous CS) followed by 
Group 2b (primi, term, cephalic, induced labor) and the major contributor to primary CS rate was by Group $2 \mathrm{~b}$.
Similar finding has been noted in various Indian and international studies.

Table 2: Results.

\begin{tabular}{|c|c|c|c|c|c|c|c|}
\hline Group & Subgroup & $\begin{array}{l}\text { No. of } \\
\text { women } \\
\text { in the } \\
\text { group } \\
\text { (a) }\end{array}$ & $\begin{array}{l}\text { Relative } \\
\text { size of } \\
\text { group } \\
(\%)(b)\end{array}$ & $\begin{array}{l}\text { No. of } \\
\text { CS } \\
\text { (c) }\end{array}$ & $\begin{array}{l}\text { CS rate in } \\
\text { the group } \\
(\%)(d)\end{array}$ & $\begin{array}{l}\text { Contribution } \\
\text { to overall CS } \\
(\%)(\mathrm{e})\end{array}$ & $\begin{array}{l}\text { Contribution } \\
\text { to primary } \\
\text { CS }(\%)(f)\end{array}$ \\
\hline \multirow{3}{*}{$\begin{array}{l}\text { Nulliparous, single, } \\
\text { cephalic, equal to or } \\
>37 \text { weeks }\end{array}$} & A) Spontaneous & 178 & 13.3 & 8 & 4.4 & 1.9 & 5.03 \\
\hline & B) Induced & 217 & 16.2 & 49 & 22.5 & 11.8 & 30.8 \\
\hline & $\begin{array}{l}\text { C) CS before } \\
\text { labour }\end{array}$ & 26 & 1.9 & 26 & 100 & 6.2 & 16.3 \\
\hline \multirow{3}{*}{$\begin{array}{l}\text { Multiparous, single, } \\
\text { cephalic, equal to or } \\
\text { >37 weeks (excluding } \\
\text { previous CS) }\end{array}$} & A) Spontaneous & 233 & 17.4 & 2 & 0.8 & 0.4 & 1.2 \\
\hline & B) Induced & 125 & 9.3 & 10 & 8 & 2.4 & 6.28 \\
\hline & $\begin{array}{l}\text { C) CS before } \\
\text { labour }\end{array}$ & 5 & 0.37 & 5 & 100 & 1.2 & 3.1 \\
\hline \multirow{3}{*}{$\begin{array}{l}\text { All single, cephalic } \\
<37 \text { weeks (excluding } \\
\text { previous CS) }\end{array}$} & A) Spontaneous & 87 & 6.5 & 3 & 3.4 & 0.7 & 1.8 \\
\hline & B) Induced & 89 & 6.6 & 8 & 8.9 & 1.9 & 5.03 \\
\hline & $\begin{array}{l}\text { C) CS before } \\
\text { labour }\end{array}$ & 14 & 1.04 & 14 & 100 & 3.38 & 8.8 \\
\hline \multirow{3}{*}{ All nulliparous breech } & A) Spontaneous & 9 & 0.67 & 1 & 11.1 & 0.2 & 0.6 \\
\hline & B) Induced & 7 & 0.5 & $0 ?$ & 0 & 0 & 0 \\
\hline & $\begin{array}{l}\text { C) CS before } \\
\text { labour }\end{array}$ & 18 & 1.3 & 18 & 100 & 4.3 & 11.3 \\
\hline \multirow{3}{*}{$\begin{array}{l}\text { All multiparous breech } \\
\text { (excluding previous } \\
\text { CS) }\end{array}$} & A) Spontaneous & 4 & 0.29 & $0 ?$ & 0 & 0 & 0 \\
\hline & B) Induced & 2 & 0.14 & $0 ?$ & 0 & 0 & 0 \\
\hline & $\begin{array}{l}\text { C) CS before } \\
\text { labour }\end{array}$ & 2 & 0.14 & 2 & 100 & 0.4 & 1.2 \\
\hline \multirow{3}{*}{$\begin{array}{l}\text { All multiple } \\
\text { pregnancies } \\
\text { (excluding previous } \\
\text { CS) }\end{array}$} & A) Spontaneous & 21 & 1.5 & $0 ?$ & 0 & 0 & 0 \\
\hline & B) Induced & 8 & 0.59 & $1 ?$ & 12.5 & 0.2 & 0.6 \\
\hline & $\begin{array}{l}\text { C) CS before } \\
\text { labour }\end{array}$ & 8 & 0.59 & 8 & 100 & 1.9 & 5.03 \\
\hline \multirow{3}{*}{$\begin{array}{l}\text { All abnormal lies } \\
\text { (excluding previous } \\
\text { CS) }\end{array}$} & A) Spontaneous & 2 & 0.14 & 0 & 0 & 0 & 0 \\
\hline & B) Induced & 1 & 0.07 & 1 & 100 & 0.2 & 0.6 \\
\hline & $\begin{array}{l}\text { C) CS before } \\
\text { labour }\end{array}$ & 3 & 0.14 & 3 & 100 & 0.7 & 1.8 \\
\hline \multicolumn{2}{|c|}{$\begin{array}{l}\text { Total (last column shows primary CS } \\
\text { rate) }\end{array}$} & $X=1059$ & & $Y=159$ & & & $\mathrm{Y} / \mathrm{x} \times 100=15 \%$ \\
\hline \multicolumn{2}{|c|}{ All previous CS } & 278 & 20.79 & 254 & & 61.5 & \\
\hline
\end{tabular}

Ray A et al has shown that women with previous CS contributes maximum to overall CS rates followed by term primigravidas who are induced or underwent CS before labour (group 2 of original Robson's classification). ${ }^{4}$

Similar findings were noted by Kazmi $\mathrm{T}$ et al, Helena et al and Tanaka et al. ${ }^{5-7}$ These and many other authors have highlighted on encouraging for TOLAC in order to reduce repeat sections. Attempts to reduce Repeat CS (by promoting TOLAC) for reducing overall CS rate may be under taken by full-fledged obstetric units with dedicated staff with careful selection of cases. Most often those who achieve a VBAC are mothers who come in active labour with advanced cervical dilatation, others end up with a repeat $\mathrm{CS}$ to avoid the burden of intensive monitoring and risk of medico legal issues if mishap occurs. Our modified classification system for CS mainly focuses on analyzing the Primary CS rate (and thus ways to reduce it) but at the same time previous CS and its mode of delivery is also studied separately.

Labour induction protocols vary worldwide and multiple authors have quoted increasing labour inductions as an upcoming contributor to caesarean deliveries, especially primary CS rates. Studies have suggested this as one of the major modifiable factor in reducing primary CS rates whereby we can reduce repeat CS also. Study by Ann M et al have found induced primigravidas underwent major proportion of primary sections. ${ }^{8}$ Yadav et al have found 
induced primigravidas contribute even more than the previous CS group to overall CS rate. ${ }^{9}$ Mbaye et al has also noted similar results. ${ }^{10}$ Pandey et al suggested that the best way to reduce overall CS is to prevent primary CS. ${ }^{11}$ For this, improved case selections for labour induction and pre labour CS in of utmost importance.

Malpresentations, especially Breech presentations also contributes significantly to overall as well as primary CS rates in the present study. Sneha et al have noted $100 \%$ CS rate in Breech presentations regardless of parity. ${ }^{12}$ Samba et al have also noted high section rates in Breech and has recommended increase use of ECV in breech presentations and conduct of vaginal breech deliveries. ${ }^{13}$

ACOG has set definite guidelines on labor management aiming to limit growing primary caesareans. ${ }^{14}$ They have suggested to include strategies to avoid unindicated early labour inductions and to promote ECV for Breech and twin vaginal deliveries.

Attempts to modify the original Robson system has been tried previously by few authors. Similar subdivision of each of the ten groups in original Robsons classification has been tried in Canada to make it more informative; though induction in women with previous scarred uterus remains a controversy. ${ }^{15}$ Dr Prameela RC et al have also suggested modifications in the existing system, particularly subdivision of group 3 and 4 based on indications for $\mathrm{CS}$, in order to find out exact reason for increase in CS rate. ${ }^{16}$

The primary advantage of this modified system is that it gives a clear idea regarding women undergoing CS and thus helps to identify areas requiring interventions at the health care level to reduce CS rates; which is a growing concern in the obstetric population. The original classification categorized women mainly based on their present obstetric characteristics, with less importance to previous obstetric events. Hence, women with or without a scarred uterus were scattered in multiple groups.

The modified system classifies women with previous CS into separate group regardless of their other obstetric characteristics. Hence it helps to directly measure the Primary as well as the Repeat CS rates separately. It indirectly measures VBAC rates also. The recommendations of WHO in 1985 to have a CS rates of $10-15 \%$ of total deliveries may be corrected as a primary CS rate of around $15 \%$ considering the increasing number of CS for previous CS cases in the present obstetric scenario. Our target should be to achieve a practical target of a primary CS rate of around $15 \%$ which will definitely reduce previous CS in the long run.

\section{Limitations of this study were:}

- Total no. of women with a particular obstetric feature cannot be obtained (e.g. total no pf multiple pregnancies/ breech as some of them may be included in previous CS group (Group 8)

- Level of prematurity not assessed

- Women with previous CS who tried TOLAC is not clear

- Those with previous CS not delivered by a repeat CS may not always VBAC as rarely it may be delivery by laparotomy due to rupture of the scar.

\section{CONCLUSION}

TMC modified Robson's classification can be effectively utilized in analysing delivering women and provides more clear and valuable information regarding the delivery characteristics with particular concentration on separately studying primary and repeat CS.

\section{Funding: No funding sources}

Conflict of interest: None declared

Ethical approval: The study was approved by the Institutional Ethics Committee

\section{REFERENCES}

1. Robson M, Murphy M, Byrne F. Quality assurance: the 10-group classification system (Robson classification), induction of labour and cesarean delivery. Int J Gynecol Obstet. 2015:S23-7.

2. Betran AP, Vindevoghel N, Souza JP, Gulmezoglu AM, Torloni MR. A systematic review of the Robson classification for caesarean section: what works, doesn't work and how to improve it. PloS One. 2014;9(6):e97769.

3. Makhanya V, Goender L, Moodley J. Utility of Robson ten group classification system to determine appropriateness of caesarean sections at a rural region hospital in Kwazulu-Natal, South Africa. South Africa Med J. 2015;105:4.

4. Ray A, Jose S. Analysis of caesarean section according to Robson's ten group classification system and evaluating the indications within the groups. Int J Reprod Contracept Obstet Gynecol. 2017;6(2):447-51.

5. Kazmi T, Saiseema SV, Khan S. Analysis of caesarean section rate according to Robson's 10 group classification, Oman Med J. 2012;27(5):415-7.

6. Litorp H, Kidanto HL, Nystrom L, Darj E, Essen B. Increasing caesarean section rates among low-risk groups: a panel study classifying deliveries according to Robson at a university hospital in Tanzania. Bio Med Centre Pregnancy Childbirth. 2013;13:107.

7. Tanaka K, Mahomed K. The ten group Robson classification: a single center approach identifying strategies to optimize caesarean section rates. Obstet Gynecol Int. 2017:5648938.

8. Davey MA, King J. Caesarean section following induction of labor in uncomplicated first births a population based cross sectional analysis of 42950 births. Bio Med Central Pregnancy Childbirth. 2016;16:92. 
9. Yadav RG, Maitra N. Examining caesarean delivery rates using the Robson's ten group classification. J Obstet Gynaecol Ind. 2016;66(S1):S1-S6.

10. Mbaye M, Gueye M, Gueye MDN, Niang NKS, Moreau JC. Analysis of caesarean section rate according to Robson's classification in an urban health center in Senegal. Int $\mathbf{J}$ Reprod Contracept Obstet Gynecol. 2015;4(4):1100-2.

11. Pandey D. Robson criteria: an emerging concept. Open Access J Gynecol. 2017;2(2):2474-9230.

12. Dhodapkar SB, Bhairavi S, Daniel M, Chauhan NS, Chauhan RC. Analysis of caesarean sections according to Robson's ten group classification system at a tertiary care teaching hospital in south India. Int J Reprod Contracept Obstet Gynecol. 2015;4(3):745-9.

13. Samba A, Mumuni K. A review of caesarean sections using the ten-group classification system in the Korle-Bu teaching hospital, Ghana. Gynaecol Obstet J. 2016;6(6).

14. Farine D, Shepherd D. Classification of caesarean sections in Canada: the modified Robson criteria. J Obstet Gynecol Canada. 2012;34(10):976-9.

15. Prameela RC, Farha A, Bhanumathi PM, Prajwal S. Analysis of caesarean section rate in a tertiary hospital according to Robson's ten group classification system. IOSR J Dent Med Sci. 2015;14(2):46-9.

Cite this article as: Jacob KJ, Jayaprakash M, Hibina KP. TMC (Thrissur Medical College) modified Robson criteria for caesarean sections. Int $\mathbf{J}$ Reprod Contracept Obstet Gynecol 2017;6:5038-43. 